\title{
Waste management based on circular economy principles
}

\author{
Olga Guman ${ }^{1}$, and Ekaterina Wegner-Kozlova ${ }^{2,3, *}$ \\ ${ }^{1}$ Ural State Mining University, 620144, Kuibyshev st., 30, Ekaterinburg, Russia \\ ${ }^{2}$ Institute of Economics The Ural Branch of Russian Academy of Sciences, 620014, Moscow str., 29, \\ Ekaterinburg, Russia \\ ${ }^{3}$ Ural Federal University named after the first President of Russia B.N. Yeltsin, 620014, Lenin str., \\ 13B, Ekaterinburg, Russia
}

\begin{abstract}
Waste management has strategic implications in contemporary world. The demand in combination of economic development with environmental safety is urging to focus on capacities of non-linear economy. Waste management should redirect its efforts to reduction, recycling and treatment techniques, which view the wastes as resources. The goal of this paper is to study theoretical and practical issues of waste management based on circular economy principles from perspective of cross-disciplinary eco-economic collaboration.
\end{abstract}

\section{Introduction}

Humankind is facing many environmental challenges at the current stage of economy development. Land degradation, deterioration of resource potential, increase of waste volume are global challenges for the current and next generations. Special attention is paid to the waste management agenda. As V.I. Vernadsky stated, "not a single organizm can survive in its own waste. The waste must be a part of nature's cycle, they should be disposed of and used" [1]. At the United Nations Conference on Environment and Development (Earth Summit) in 1992, the goal of sound management of the wastes was identified as one of the key goals in terms of maintaining the quality of the Earth's environment. Significance of solid waste management was highlighted again at the World Summit on Sustainable Development in 2002. It was pointed out that priority must be given to prevention, minimization, recycling and treatment of wastes [2]. To ensure sustainable development the wastes should be prevented, minimized, recycled and processed (Fig.1).

\footnotetext{
${ }^{*}$ Corresponding author: katya.human@mail.ru
} 

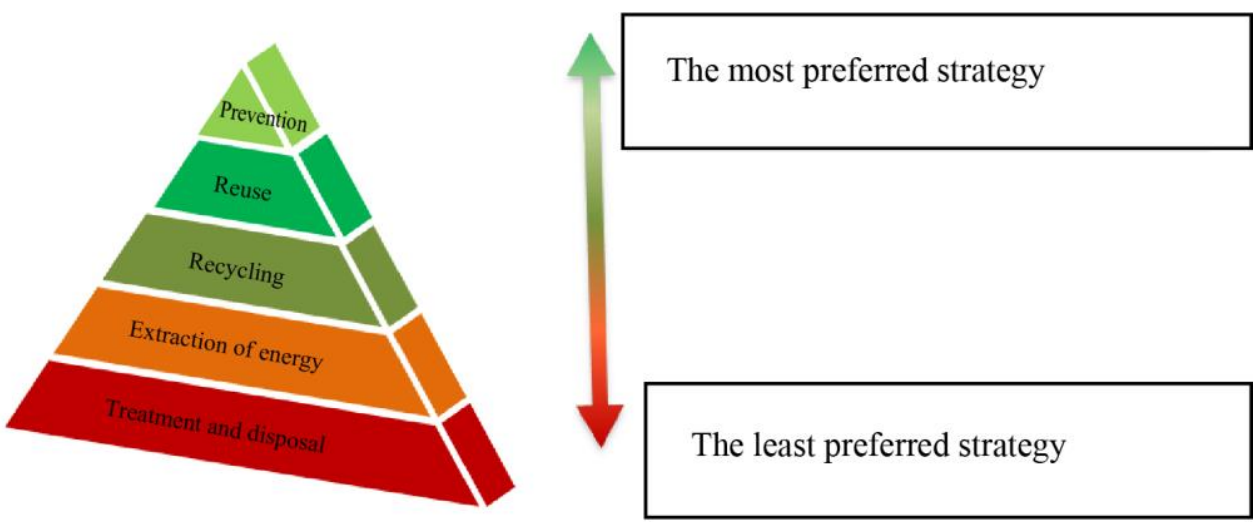

Fig.1. Hierarchy of waste management strategies [2]

There is no doubt that global trend of waste increase presents a threat to eco-economic sustainability. To implement the prevention strategy, the waste management process requires interdisciplinary researches and collaborations, groundbreaking transformations and improvements. This challenge is relevant to many stakeholders (government, regional and local authorities, population, academic communities, business communities etc.), requires behavioral adjustments, reframing existing waste management systems and reorientation to prevailing concepts of circular economy (CE).

Circular economy is a sustainable development initiative targeting reduction of straightline relationship of social systems of production and consumption. It features utilization of material cycles, renewable and cascaded energy flows to a linear system. CE encourages development of high value material cycles along with more conventional treatment and develops system approaches to collaboration of manufacturers, consumers and other agents of society within sustainable development dimension [3]. Circular economy describes economical system based on business models, which replace the "end of life" concept of by reduction, reuse, recycling of materials in production processes or in their distribution and consumption. It functions on microscale level (products, companies, consumers), mesolevel (eco-industrial parks) and macroscale level (city, region, nation, global level) in order to achieve sustainable development, which implies development of high quality environment, economic prosperity and social equity, for the benefit of current and next generations [4].

Basic principles of "3R" circular economy:

1. Reduce

2. Reuse

3. Recycle

The state government bodies will face the need to refer to principles of circular economy for achievement of required extent of eco-economical sustainability and competitive power at global level more often. The practice of advanced economies shows active concern of the global community with improvement of environmental conditions along with simultaneous economic development and growth, which is detailed in development of legal and regulatory framework of CE. "The Basic Act for Establishing a Sound Material-Cycle Society" was enacted in Japan in 2002. China became the first country that referred to $\mathrm{CE}$ directly in their regulation, having adopted the Law "Concerning stimulation of circular economy" in 2009. The European Union encourages 
and develops implementation of principles of circular economy by means of political measures and measures targeting achievement of considerable effect throughout the whole cycle of resource utilization, from production and consumption to treatment of wastes and waste management. Germany was one of the first countries to introduce dual waste collection system and legislations to regulate closed cycles of materials and waste management. The efforts in Denmark were concentrated on designing products, changing business models and design strategies. In particular, that applies to engineered consumer products (electronics, cars) and high-quality production. The university research centers and projects funded by the EU were focused on CE principles, encouraging its development. The European Commission promoted the release of the European documentation package, which supported implementation of cutting-edge practice of CE, in 2015 [5]. The concept of circular economy is of special relevance to areas facing seemingly controversial problem of combining economic development with protection of favorable environment.

\section{Materials and Methods}

Waste management gains strategic implications in contemporary world. Until recently, the evolution of industrial activity was studied in terms of linear system of consumption of resources that was common for all countries and implied the following: collection and extraction of resources $\rightarrow$ manufacturing the product $\rightarrow$ handing over the product to consumer $\rightarrow$ disposal of the product. However, the need to combine economic development with environmental safety urged to focus on capacities of non-linear flowchart, implying "reusability" concept of economy. In accordance with the objectives of circular economy, waste management should redirect its efforts to reduction, recycling and treatment techniques in favor of all stakeholders (government bodies, citizens, experts, business entities). The waste treatment practice undergoes transformation from simple collection and sorting procedure to generation of sustainable systems [6], in terms of which the wastes are considered as potential resources.

Transition to circular economy can not take place without association with active crossdisciplinary collaboration. On one hand, the goals set by circular economy require application of general scientific approaches: deductive/inductive approach, including hypothetic-deductive approach, analysis and synthesis, institutional analysis, statistical, comparative and cause-consequence analysis, factor analysis, analogue method, historical method capable of taking into account historical, social, and cultural particulars of economy, and other general-theoretical approaches. On the other hand, they require specific knowledges about environmental processes. Processing geoenvironmental data, hydrogeological data, landscape - geochemical data, geotechnical survey data, analytical and experimental efforts in laboratories and field conditions must be associated with specific approaches related to the subject-matter in question. Application of physical and computerized simulation techniques utilizing GIS technologies and analytical study in laboratories is also included.

\section{Results and Discussion}

Fundamental condition of implementation of circular economy is to take into account geographical, environmental, economic, social factors and other specific features of individual territories. Diversity of territorial contexts results in different demands and opportunities that must be taken into account at implementation of CE [7]. The waste management challenges become more essential in industrial areas (regions with high share 
of mining and processing domain in structure of Gross Regional Product). As the basis of development of the national economy (which is connected with transformation processes of technostructure and improvement of production and consumption processes), these industrial areas take leadership in degradation of the environmental system, at the same time.

The Ural Region is characterized by extensive development of such economic activities as iron-and-steel and non-ferrous industry, construction, chemical production, mining operations, including gold mining. Industrial development of the region is associated with implementation of metal leaching technologies, development of deep levels and deposits with lower contents of the minerals. All that promotes aggravation of contradictions, since business is primarily focused on profit.

Table 1. Amounts of industrial waste and consumer waste [8]

\begin{tabular}{|c|c|c|c|c|c|c|c|c|c|c|c|}
\hline \multirow{3}{*}{$\begin{array}{c}\text { No. of } \\
\text { line }\end{array}$} & \multirow{3}{*}{$\begin{array}{l}\text { Description of } \\
\text { indicator }\end{array}$} & \multicolumn{10}{|c|}{ Years } \\
\hline & & \multicolumn{2}{|c|}{2014} & \multicolumn{2}{|c|}{2015} & \multicolumn{2}{|c|}{2016} & \multicolumn{2}{|c|}{2017} & \multicolumn{2}{|c|}{2018} \\
\hline & & 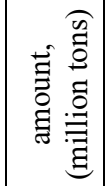 & 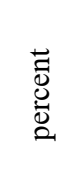 & 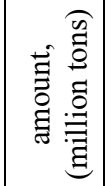 & 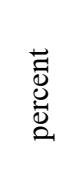 & 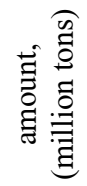 & 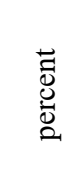 & 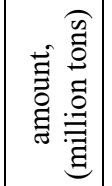 & 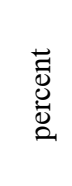 & 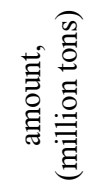 & 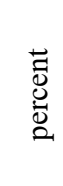 \\
\hline 1. & Generated waste & 185.2 & 100 & 179.5 & 100 & 177.0 & 100 & 166.9 & 100 & 154.9 & 100 \\
\hline 1.1 . & $\begin{array}{l}\text { of those, I-IV class } \\
\text { of hazard }\end{array}$ & 11 & - & 10.5 & - & 7 & - & 6.25 & - & 6.11 & - \\
\hline 2. & $\begin{array}{l}\text { Recycled, treated } \\
\text { waste }\end{array}$ & 84.2 & 45.5 & 83.7 & 46.6 & 79.4 & 44.9 & 69.7 & 41.8 & 62.2 & 40.2 \\
\hline 3. & $\begin{array}{l}\text { Disposed waste and } \\
\text { at temporary } \\
\text { storage }\end{array}$ & $\begin{array}{l}105.9 \\
\end{array}$ & 57.2 & 101.3 & 56.2 & 100.8 & 56.9 & 98.5 & 59 & 93 & 60 \\
\hline 4. & $\begin{array}{l}\text { Amount of waste by } \\
\text { end of the year }\end{array}$ & $9,132.6$ & - & $9,214.3$ & - & 9,295 & - & $9,369.9$ & - & 9,388 & - \\
\hline
\end{tabular}

Traditional industrial development of economy of the region identified the main source of waste. The main volume of generation, recycling and disposal of waste is concentrated by economic operators specializing in mining $(85.3 \%$ - generation of waste, $83.5 \%$ recycle of waste and $90.3 \%$ - storage of wastes) [8]. According to data provided by the Governmental report "Concerning condition and protection of environment in the Sverdlovsk Region in 2018", economic operators specializing in manufacturing activities $(9.12 \%)$, incl. metallurgical production $(7.75 \%)$ indicate significant amount of generated waste (Fig. 2).

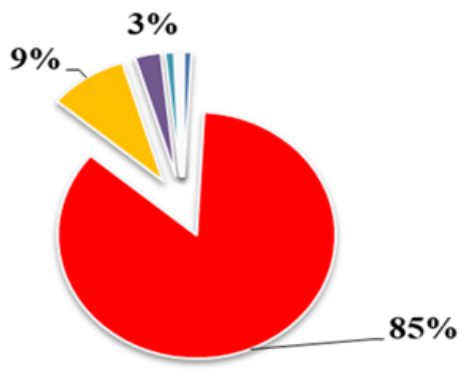

- Mining operations

- Manufacturing

Fig 2. Structure of waste generation volume divided by economic activities in the Sverdlovsk Region 
Contemporary mining plants generate considerable waste flows, which need management and planning to the effect of reduction and recycling, recovery of resources and protection of the environment [9]. Prioritizing the waste management strategies (Fig.1) graphically demonstrates that prevention of wastes is the most preferred option, whereas their recycling and treatment remain the least preferred strategy. Nevertheless, it is clear that the least preferred strategy characterizes the Sverdlovsk Region, which determines the need to analyze the opportunities and approaches to transition to the best strategies aimed at protection of the environment in the long term.

Another trend characterizing the Sverdlovsk Region is increase of solid municipal waste (SMW) (Table 2).

Table 2. Amounts of municipal waste, thousand tons [8]

\begin{tabular}{|c|l|c|c|c|c|}
\hline $\begin{array}{c}\text { No. of } \\
\text { line }\end{array}$ & \multicolumn{1}{|c|}{ Description of indicator } & 2015 & 2016 & 2017 & 2018 \\
\hline 1. & Total waste generated & $1,765.8$ & $1,641.5$ & $1,760.5$ & $1,974.8$ \\
\hline 1.1. & of those, SMW & $1,380.8$ & $1,285.5$ & 1,414 & 1,542 \\
\hline 2. & $\begin{array}{l}\text { Recycled and treated municipal } \\
\text { waste by economic operators, total }\end{array}$ & 217.6 & 178.2 & 163.1 & 156.8 \\
\hline 2.1. & of those, SMW & 164.5 & 163.4 & 155.9 & 139.9 \\
\hline 3. & $\begin{array}{l}\text { Disposed, including wastes at } \\
\text { temporary storage, total }\end{array}$ & $1,432.1$ & $1,480.9$ & $1,502.5$ & $1,766.9$ \\
\hline 3.1. & of those, SMW & $1,218.4$ & $1,124.8$ & $1,204.4$ & $1,441.3$ \\
\hline 4. & Amount of waste by end of the year & $60,595.3$ & $58,789.7$ & 60,072 & $62,021.6$ \\
\hline
\end{tabular}

The specified trends do not apply to the Sverdlovsk Region only, they represent the Ural Region in general. Prevailing types of waste determine the most relevant waste management domains (Table 3).

Table 3. Waste management options based on $3 R$ principles in the Urals

\begin{tabular}{|l|l|l|}
\hline $\begin{array}{l}\text { Prevailing waste in the } \\
\text { Urals }\end{array}$ & $\begin{array}{l}\text { Options of reduction, reusing and } \\
\text { recycling (3 R) }\end{array}$ & $\begin{array}{l}\text { 3R implementation } \\
\text { cases (company names) }\end{array}$ \\
\hline $\begin{array}{l}\text { Iron-and-steel mining } \\
\text { waste }\end{array}$ & $\begin{array}{l}\text { Ballast material } \\
\text { Recultivating material } \\
\text { As shale baffles } \\
\text { As construction materials } \\
\text { As additives to construction materials }\end{array}$ & $\begin{array}{l}\text { EVRAZ } \\
\text { company }\end{array}$ \\
\hline $\begin{array}{l}\text { Non-ferrous metals mining } \\
\text { waste }\end{array}$ & $\begin{array}{l}\text { Ballast material } \\
\text { Recultivating material } \\
\text { As shale baffles } \\
\text { As construction materials } \\
\text { As additives to construction materials }\end{array}$ & $\begin{array}{l}\text { JSC "Ural Mining \& } \\
\text { Metallurgical } \\
\text { Company" } \\
\text { JSC "Russian Copper } \\
\text { Company" }\end{array}$ \\
\hline $\begin{array}{l}\text { Nonmetallic feed mining } \\
\text { waste }\end{array}$ & $\begin{array}{l}\text { As construction materials } \\
\text { As additives to construction materials } \\
\text { As shale baffles } \\
\text { Ballast material }\end{array}$ & SLK Cement \\
\hline $\begin{array}{l}\text { Energy minerals (coal) } \\
\text { mining waste }\end{array}$ & $\begin{array}{l}\text { As construction materials } \\
\text { Recultivating material }\end{array}$ & $\begin{array}{l}\text { OJSC "Chelyabinsk } \\
\text { Coal Company" }\end{array}$ \\
\hline Cleaning rejects (tailings) & $\begin{array}{l}\text { As mineral } \\
\text { As additives to construction materials } \\
\text { Recultivating material }\end{array}$ & $\begin{array}{l}\text { PJSC "Gaisky Mining } \\
\text { Processing Plant" }\end{array}$ \\
\hline $\begin{array}{l}\text { Metallurgical production } \\
\text { waste (blast-furnace slag } \\
\text { steelmaking slag) }\end{array}$ & $\begin{array}{l}\text { As mineral } \\
\text { As additives to construction materials } \\
\text { As construction materials } \\
\text { Recultivating material }\end{array}$ & JSC "Karabashmed" \\
\hline
\end{tabular}




\begin{tabular}{|l|l|l|}
\hline & Ballast material & \\
\hline $\begin{array}{l}\text { Water treatment and water } \\
\text { purification waste }\end{array}$ & $\begin{array}{l}\text { Recultivating material } \\
\text { As additives to fertilizers }\end{array}$ & $\begin{array}{l}\text { Ekaterinburg municipal } \\
\text { unitary enterprise } \\
\text { "Vodokanal" }\end{array}$ \\
\hline Municipal waste & $\begin{array}{l}\text { Recultivating method } \\
\text { As recyclable materials }\end{array}$ & $\begin{array}{l}\text { Ekaterinburg municipal } \\
\text { unitary enterprise } \\
\text { "Spetsavtobaza" }\end{array}$ \\
\hline
\end{tabular}

Let's look at some case studies implementing the principles of circular economy in more details.

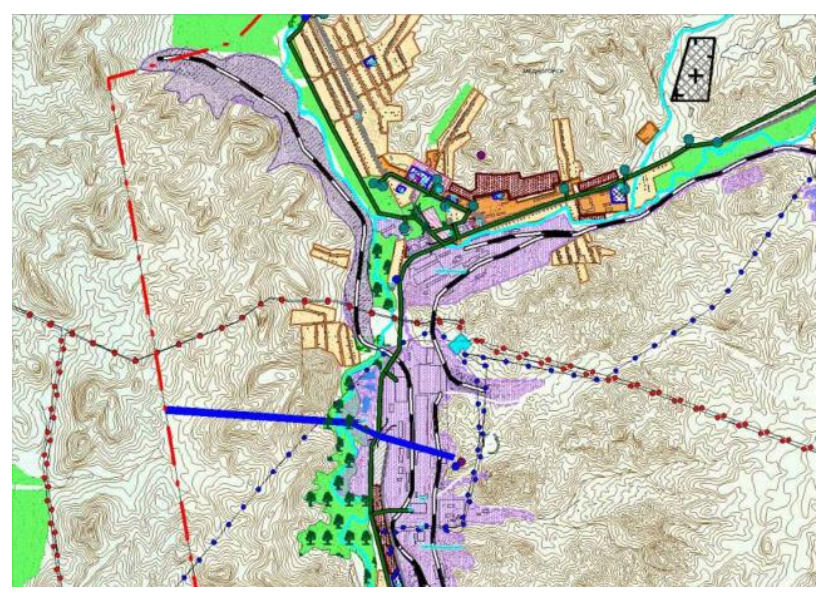

Fig. 3. Using slags as the ballast bed

K - surface drainage direction.

Case study 1. Using the slags of metallurgical production as ballast bed of the railroad (Fig. 3). According to granulometric composition, the slags belong to crushed stone soil, content of fractions more than $10 \mathrm{~mm}$ amounts to $99.2 \%$. About $90 \%$ of slag matter contain $40.55 \%$ of silicon dioxide, $39.5 \%$ of iron, and $8.7 \%$ of calcium oxide. The composition of water extract of the slags follows: $\mathrm{pH}-9.62 ; \mathrm{Fe}-4.05 ; \mathrm{Cu}-0.70 ; \mathrm{Zn}-$ 0.085 ; As $<0.01$; Ca- $21.1 \mathrm{mpg}$. Based on results of toxicological study conducted by FSI "Center of Laboratory Analysis and Technical Metrology of the Ministry of Natural Resources of the Russian Federation in the Urals Federal District" the V class of hazard is assigned to smelter slag (non-toxic). An abandoned copper-sulphide deposit with dump and acidic underspoil waters, running off towards the town, is located at water-dividing part of the town. Neutralizing of acid water and reduction to natural $\mathrm{pH}$ of the river water take place upon their reaction with caustic slags, Fig. 4. 
Thus, the slags acted as ballast bed and geochemical barrier for acidic surface run-off.

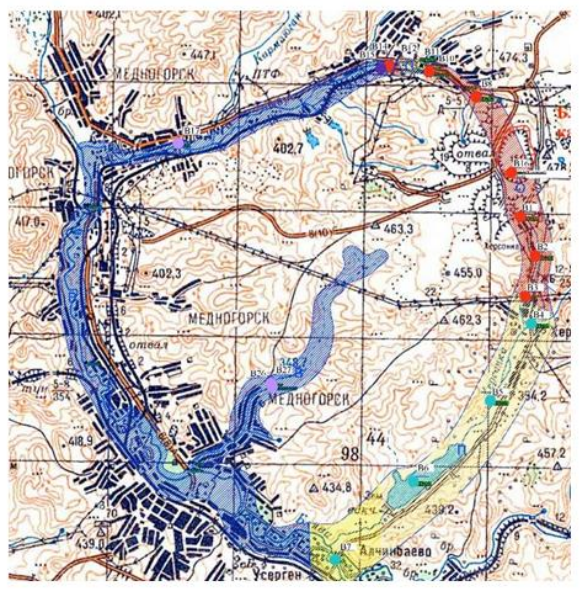

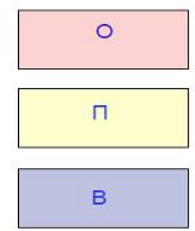

Acidic water $\mathrm{pH}$ 3-5

Subacidic water $\mathrm{pH}$ 5-6.5

Neutral water $\mathrm{pH}$ 6.5-7.5

Slightly alkaline water $\mathrm{pH} 7.5-8.5$

Alcaline water $\mathrm{pH} 8.5-9.5$

Fig.4. $\mathrm{pH}-\mathrm{Eh}$ of surface water of the survey area.

Case study 2. Processing of dump slags as source of commercial components is widely used for copper-smelting plants in the Urals in conditions of mineral raw materials shortage in recent years. Herewith, copper concentrate and cleaning rejects (sands) are produced. Initially, sands were studied in sufficient detail as recultivating material [10]. The industryrelated sands are used for recultivation of disturbed soils recently. The areas of such massifs built up by sand amount to dozens and more hectares (Fig. 5), which justifies the need to study environmental-geological properties of these man-made massifs in order to predict their impact on components of the environment.

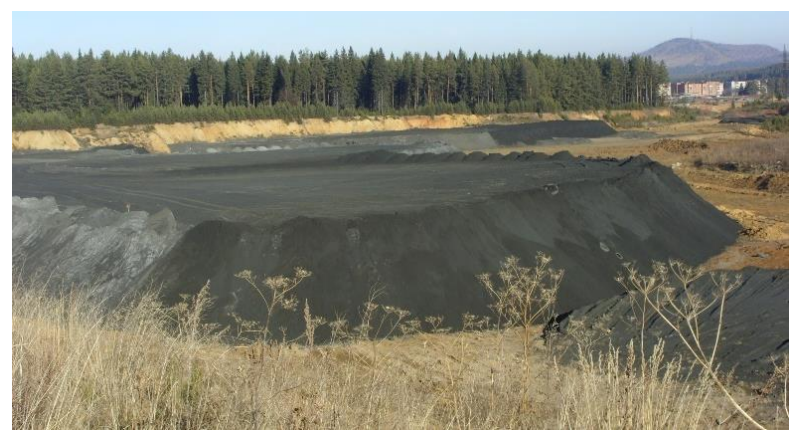

Fig. 5. Formation of industrial sand massif on disturbed soil area

Conducted surveys of soil recultivated by sand showed that it has the same type of mineral composition in the massif, same type of shape and grain size with small variations. As a rule, the grain shape is isometric, angular, and with acute angled chips. Footprint of physical impact is observed on some grains. The sand grain size ranges from $0.01 \mathrm{~mm}$ to 1 $\mathrm{mm}$. the sand represents fine agglomerated intergrowth of ore minerals with magnetic properties and nonmetallic component. The ore minerals are mainly represented by magnetite, iron sulphides, copper sulfides and other metallic phases (ferrites). Nonmetallic component mainly consists of deep brown olivine, transparent fayalite, and, probably, cristobalite, represented by fine crystal variety; also 1-2\% of quartz, up to до $2 \%$ of 
ferrum hydroxides, rare grains of carbonate rock, single Micatex (biotite) are observed (Fig. $6)$.

The main hazardous components contained in sand are heavy metals, which can't be extracted due to process features of copper smeltery and slag treatment. Chemical analysis of the main added components in sands showed increased concentrations of the following complex of chemical elements: copper, zinc, lead, arsenic and stibium, somewhat lower concentrations of tin, chrome, molybdenum and cadmium. The concentration of heavy metals in magnetic and non-magnetic fractions are the same, which points to the fact of their uniform diffusion through sand grain mass.

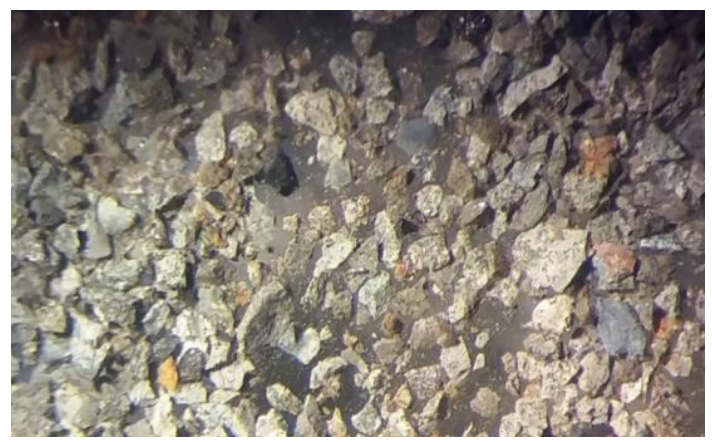

Fig. 6. Fine intergrowth of metallic and nonmetallic phases, brown films of ferrum hydroxides. Zooming 75.

This way, sands are used as recultivating material and are potential iron deposits when technology of its extraction emerges.

Case study 3. Construction sands are used as bodies of temporary motor roads (Fig. 7).

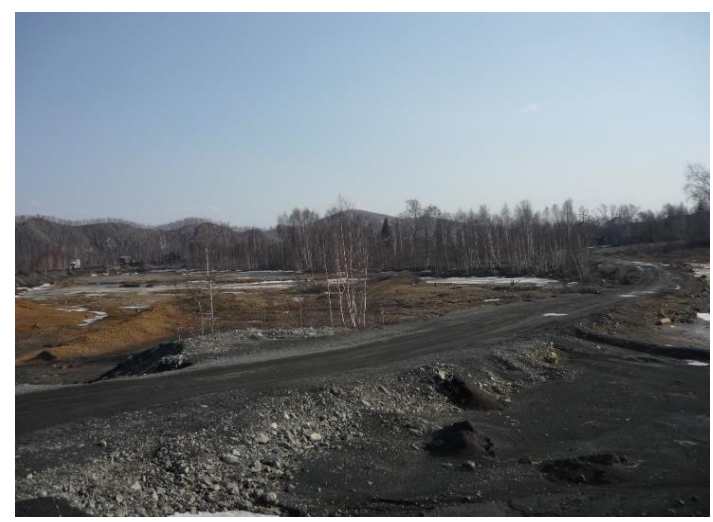

Fig. 7. Using sand for construction of temporary motor roads.

Case study 4. Production of copper slag from granulated slag produced at copper smelting. As a result of production, there are no copper particles in copper slag. The sizes of granules of the copper slag produced do not exceed $3.15 \mathrm{~mm}$, and percentage of particles having size less than $0.2 \mathrm{~mm}$ is not more than $5 \%$. Advantages of copper slag for free jet blast:

1. Strong abrasive ability owing to acute angular shape of granules and their hardness (6.0 according to Mohs scale).

2. Stabilized fractional composition of powder. 
3. Minimum humidity level, which enables the copper slag to remain granular and not to form lumps, thereby not jamming the abrasive supply line.

4. Low dust content in the powder ensuring reduction of powdery cloud during surface finishing, which makes copper slag applicable in small enclosures (e.g. barrels, railcars). [11].

5. Environmentally-friendly material, non-offensive both to humans and environment

Specifications and quality of the "Uralgrit" sand based on copper slag are as good as those of garnetiferous sand (imported from India or Australia) and electrocorundum, and the cost of this sand is less than that of Indian /Australian garnetiferous sand or electrocorundum, which highlights import substitution process.

However, practical implementation of $3 \mathrm{R}$ principles in practice is subject to requirement for conduction of extensive environmental impact assessment, since it's not impossible that implementation of a project focused on recycling, reusing or reduction can result in deterioration of environmental conditions of adjacent areas. Therefore, it is mandatory for the environmental impact assessment of waste management to include an extensive analysis of their storage locations [12].

\section{Conclusion}

Application of tools and principles of circular economy (CE) is more frequently considered as key driver to reach sustainable development goals. The reason for that is that economic activity in terms of circular economy is targeting maximized conservation of value of products, materials and resources, and minimization of amounts of polluting emissions and generated wastes, at the same time. It is clear that global trend of waste increase presents a threat to eco-economic sustainability. To achieve the most preferred waste prevention strategy, the waste management process requires cross-disciplinary researches and collaborations, groundbreaking transformations and improvements. As of today, determining economically effective and environmentally safe approaches to waste reuse, recycling and reduction is a critical goal, wherein environmental assessment of components of wastes and assessment of their long-term impact on the environment remain a high priority objective.

\section{Acknowledgements}

“The reported study was funded by RFBR, project number 20-010-00558".

\section{References}

1. V.I. Vernadsky, Primary and secondary living matter in bioenvironment, 8, 63-71 (Moscow : Science Press, 1960)

2. G. Bernd, Elements, 7, 405-410 (2011)

3. J. Korhonen, A. Honkasalo, J. Seppälä, Ecological Economics, 143, 37-46 (2018)

4. J. Kirchherr, D. Reike, M. Hekkert, Resources, Conservation \& Recycling, 127, 221232 (2017)

5. F. Silvestri, F. Spigarelli, M. Tassinari, Journal of Cleaner Production, 255 (2020)

6. A. Zhang, V.G. Venkatesh, Y. Liu, M. Wan, T. Qu, D. Huisingh, Journal of Cleaner Production, 240, 118-198 (2019)

7. M. Bačova, K. Böhme, M. Guitton, M. van Herwijnen, T. Kállay, J. Koutsomarkou, I. Magazzù, E. O’Loughlin, A. Rok, Pathways to a circular economy in cities and regions 
8. Public report $O$ Concerning environment and environmental protection in the Sverdlovsk Region in 2018

9. G. Bernd, Elements, 7, 405-410 (2011)

10. O.M. Guman, I.A. Antonova, A.B. Makarov, C.A. Alexandrov, Proceedings of the International Conference (September 27-28, 2018, Moscow State University, Moscow, Russia), 213-218 (Moscow, LLC SamPrint, 2018)

11. Uralgrit, SamPrint, corporate group website URL : www.uralcrit.com

12. I.A. Antonova, O.N. Gryaznov, O.M. Guman, A.B. Makarov, O.V. Kolosnitsina, Geological conditions for allocation of solid municipal and industrial waste disposal sites in the Middle Urals Water Resources, 41(7), 896-903 (2014) 